\title{
RESEARCH
}

Open Access

\section{Clinical situations for which 3D printing is considered an appropriate representation or extension of data contained in a medical imaging examination: adult cardiac conditions}

Arafat Ali ${ }^{*{ }^{*}}$, David H. Ballard ${ }^{2}$, Waleed Althobaity ${ }^{3}$, Andy Christensen ${ }^{4}$, Mariah Geritano ${ }^{5}$, Michelle Ho ${ }^{6}$, Peter Liacouras ${ }^{7}$, Jane Matsumoto ${ }^{8}$, Jonathan Morris ${ }^{8}$, Justin Ryan ${ }^{9}$, Rami Shorti ${ }^{10}$, Nicole Wake ${ }^{11}$, Frank J. Rybicki ${ }^{1}$, and Adnan Sheikh ${ }^{4}$ on behalf of the RSNA 3D Printing Special Interest Group

\begin{abstract}
Background: Medical 3D printing as a component of care for adults with cardiovascular diseases has expanded dramatically. A writing group composed of the Radiological Society of North America (RSNA) Special Interest Group on 3D Printing (SIG) provides appropriateness criteria for adult cardiac 3D printing indications.

Methods: A structured literature search was conducted to identify all relevant articles using 3D printing technology associated with a number of adult cardiac indications, physiologic, and pathologic processes. Each study was vetted by the authors and graded according to published guidelines.

Results: Evidence-based appropriateness guidelines are provided for the following areas in adult cardiac care; cardiac fundamentals, perioperative and intraoperative care, coronary disease and ischemic heart disease, complications of myocardial infarction, valve disease, cardiac arrhythmias, cardiac neoplasm, cardiac transplant and mechanical circulatory support, heart failure, preventative cardiology, cardiac and pericardial disease and cardiac trauma.

Conclusions: Adoption of common clinical standards regarding appropriate use, information and material management, and quality control are needed to ensure the greatest possible clinical benefit from 3D printing. This consensus guideline document, created by the members of the RSNA 3D printing Special Interest Group, will provide a reference for clinical standards of 3D printing for adult cardiac indications.
\end{abstract}

Keywords: 3D printing, Appropriateness, Guidelines, Quality, Radiology, Additive Manufacturing, Anatomic Model, Adult Cardiology, Left Atrial Appendage, Transcatheter Aortic Valve Replacement

\footnotetext{
* Correspondence: Alia4@ucmail.uc.edu

'Department of Radiology, University of Cincinnati Medical Center, Cincinnati, OH, USA

Full list of author information is available at the end of the article
}

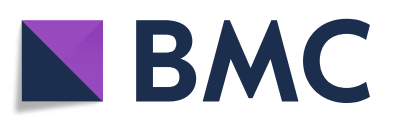

(- The Author(s). 2020 Open Access This article is licensed under a Creative Commons Attribution 4.0 International License, which permits use, sharing, adaptation, distribution and reproduction in any medium or format, as long as you give appropriate credit to the original author(s) and the source, provide a link to the Creative Commons licence, and indicate if changes were made. The images or other third party material in this article are included in the article's Creative Commons licence, unless indicated otherwise in a credit line to the material. If material is not included in the article's Creative Commons licence and your intended use is not permitted by statutory regulation or exceeds the permitted use, you will need to obtain permission directly from the copyright holder. To view a copy of this licence, visit http://creativecommons.org/licenses/by/ $4.0 /$ The Creative Commons Public Domain Dedication waiver (http://creativecommons.org/publicdomain/zero/1.0/) applies to the data made available in this article, unless otherwise stated in a credit line to the data. 


\section{Background}

In 2018, the RSNA 3D printing SIG published guidelines that include medical 3D printing appropriateness [1]. Those guidelines include 3D printing for patients with congenital heart disease. Medical 3D printing is performed for a variety of adult cardiac indications, but without evidence-based appropriate use criteria (AUC). The purpose of this document is to bridge the large unmet need to identify, vet, vote and publish appropriateness recommendations for $3 \mathrm{D}$ printing of adult cardiac indications.

\section{Methods}

The Special Interest Group has initiated quality and safety scholarship to identify those clinical situations for which adult cardiac 3D Printing is considered usually appropriate, maybe appropriate and rarely appropriate as a representation of the data contained in a medical imaging examination. This document highlights appropriateness of adult cardiac 3D printing for clinical utilization, research, scientific, and informational purposes. This work is loosely modeled after the American College of Radiology Appropriateness Criteria ${ }^{\circ}$ [2], in that the guidelines committee uses an evidence-based approach at scoring. Consensus among members is used when there is a paucity of evidence. Strength of evidence is determined by literature review.

The SIG Guidelines Chairperson oversees the ratings via a vote among Special Interest Group members who attend in-person meetings. The results of the ratings follow the following 1-9 format (with 9 being the most appropriate):

$1-3$, red, rarely appropriate: There is a lack of a clear benefit or experience that shows an advantage over usual practice.

4-6, yellow, maybe appropriate: There may be times when there is an advantage, but the data are lacking, or the benefits have not been fully defined.

7-9, green, usually appropriate: Data and experience shows an advantage to 3D printing as a method to represent and/or extend the value of data contained in the medical imaging examination.

Clinical scenarios were organized by two major cardiovascular treatises to (a) ensure an exhaustive, structured English language PubMed literature search (Additional file 1) performed October 2019, and (b) generate a document following the typical format of an Appropriate Use Criteria (AUC), including a structure using standard categories of cardiovascular disease [3, 4]. For each category, from the pool of total results, the number of publications considered "relevant results" was curated by consensus between physicians with expertise in 3D printing and cardiovascular care. 3D printing as an educational tool was not grouped in an individual category; instead, its value was considered with respect to individual clinical scenarios. Relevant publications which were not retrieved by the structured PubMed search were manually entered into the appropriate categories and indicated as such (Additional file 1). The following categories were excluded because they were considered outside the project scope (Virtual \& augmented reality, Bioprinting, Molecular biology, Genetics, Molecular imaging, Diabetes, Endocrinology, and Thrombosis) or covered elsewhere. While this document addresses adult cardiac conditions, it does not address congenital heart disease in the adult. Cardiac 3D printing review articles were not considered in determining final appropriateness ratings [5-19]. All final components of this section were vetted and approved by vote of Special Interest Group members face-to-face at the 2019 Annual Meeting of the Radiological Society of North America (December 2, 2019, Chicago, IL, USA). In addition, all included studies [20-143] were graded with a strength of evidence assessment (Additional file 2) according to the ACR Appropriateness Criteria ${ }^{\circ}$ Evidence Document [144].

\section{Results}

This section provides evidence-based guidelines, supplemented by expert opinion when there is a paucity of peer-review data, to define and support the use of 3D printing for patients with adult cardiac disease [Table 1]. A total of 135 articles published between February 2007 and October 2019 were ultimately included in the evidence base (Additional file 1). The citations included in forming the appropriateness criteria and the strength of evidence assessment are presented in Additional files 1 and 2 , respectively.

\section{Discussion}

\section{Cardiac fundamentals}

3D printed anatomic models provide a unique avenue for the study of complex hemodynamic function. Several research methods study cardiac hemodynamics using a 3D printed model [20-27], but none are applied clinically. No clinical applications exist on cardiac pathology or resuscitation.

\section{Perioperative and intraoperative care}

A single study evaluated the feasibility of $3 \mathrm{D}$ printed models for evaluating flow dynamics extracorporeal circulation [21]; however, this study was not for direct use in patient care.

\section{Coronary disease and ischemic heart disease}

Acute myocardial infarction is a life threatening cardiac emergency with significant associated morbidity and mortality [145]. Lead time for 3D segmentation and 
Table 1 Appropriateness Ratings for Adult Cardiac Indications

Clinical Condition
Cardiac Fundamentals
Cardiovascular Pathology
Cardiovascular Physiology
Electrocardiography
Cardiac Resuscitation

Coronary Disease and Ischemic Heart Disease

Coronary Artery Disease and Myocardial Infarction
Coronary Artery Fistula
Coronary Artery Aneurysm
Coronary Artery Bypass
Post-Surgical Infarction
Atherosclerosis
Chest pain, angina

\section{Complications of myocardial Infarction}

Left ventricular aneurysm

Post infarct ventricular septal defect

Myocardial rupture, acute

Myocardial rupture, chronic

Left ventricle pseudoaneurysm

\section{Aortic Valve Disease}

Transcatheter aortic valve replacement

Surgical Aortic valve replacement

\section{Mitral Valve Disease}

Transcatheter Mitral Valve Replacement

Surgical Mitral Valve Replacement

\section{Tricuspid Valve Disease}

Tricuspid valve repair/replacement

\section{Pulmonic Valve Disease}

Pulmonary valve repair/replacement

\section{Cardiac Arrhythmias}

Cardiac Arrhythmia/atrial fibrillation

Cardiac Pacing

\section{Cardiac Neoplasm}

Cardiac Tumors

\section{Cardiac Transplant and Mechanical Circulatory Support}

Left Ventricular Assist device

Total Artificial Heart

\section{Heart Failure}

Heart Failure

\section{Preventative Cardiology}


Table 1 Appropriateness Ratings for Adult Cardiac Indications (Continued)

\begin{tabular}{lll}
\hline Clinical Condition & Rating & References \\
\hline Left atrial appendage occlusion & $\mathbf{9}$ & {$[115-132]$} \\
Cardiac and Pericardial Disease & & $\mathbf{9}$ \\
Hypertrophic Cardiomyopathy & $\mathbf{5}$ \\
Dilated and restrictive cardiomyopathy & $\mathbf{3}$ \\
Infectious and inflammatory conditions of the heart & $\mathbf{4}$ \\
Pericardial Disease & \\
Cardiac Trauma & $\mathbf{1}$ \\
Cardiac trauma & - \\
\hline
\end{tabular}

printing precludes the availability of anatomic models for real time procedural planning percutaneous intervention. As such, there are minimal results for the use of 3D printed models for myocardial infarction. Several authors assess the feasibility of 3D printed models for studying coronary arterial flow dynamics, but the results were not directly applied to patient care [22-27]. There are several published case reports of 3D printed models used in procedural planning for coronary artery aneurysm and fistula repair [33-36].

\section{Complications of myocardial infarction}

Complications of myocardial infarction may require surgical management, as in the single case reports of a left ventricular pseudoaneurysm and post infarct ventricular septal defect, where a model was used for procedural planning $[37,38]$.

\section{Valve disease}

Paravalvular leak is a potentially life-threatening complication of transcatheter valve replacement. Although no large-scale prospective studies have been performed, there is growing body of case reports, suggesting decreased incidence of paravalvular leak and improved outcomes for transcatheter aortic and mitral valve replacement planned with the use of a 3D printed anatomic model [20, 39-59, 63-81]. Complicated surgically placed aortic and mitral valve replacements, as well as pulmonary or tricuspid valves, may also benefit from anatomic models [60-62, 82-98].

\section{Cardiac arrhythmias}

Irregular heart rhythms refractory to medical therapy may require cardiac ablation or pacemaker placement for definitive therapy. Published uses of anatomic models include case reports for procedural planning in cases with complex anatomy [99-102].

\section{Cardiac transplant and mechanical circulatory support}

Cardiac transplantation is indicated in patients with end-stage heart failure who are symptomatic, despite optimization of medical therapy. Approximately 3200 transplantations are performed annually in the United States [146]. Anatomic models can potentially reduce operative time and outcomes for this complex surgical procedure. To date, there is only a single case report describing the use of a 3D printed model in an adult requiring a surgically challenging cardiac transplant with congenital heart disease [111].

Left ventricular assistive devices (LVAD) are a temporizing procedure for patients pending definite cardiac transplantation. An anatomic model was used to guide cannula placement and trabeculae resection in a single case report for LVAD placement [113].

\section{Heart failure}

Heart failure portends a wide variety of causes and is usually managed with medical therapy preceding definitive cardiac transplantation. As such, no published articles describe the utility of 3D models for heart failure.

\section{Preventative cardiology}

Patients with atrial fibrillation carry increased risk for stroke and a large meta-analysis of left atrial appendage closure demonstrates noninferiority compared with anticoagulation in patients with nonvalvular atrial fibrillation [147]. Growing evidence suggests superior outcomes with device sizing guided by an anatomic model [115-131].

There is no published evidence for the utility of anatomic models in the management of blood pressure disorders.

\section{Cardiac and pericardial disease}

Accurate septal myectomy is the determinant of outcomes in surgical management of hypertrophic obstructive cardiomyopathy. Anatomic models can help to achieve superior intraventricular septum resection volume and shape [133-143].

Limited surgical options exist for dilated cardiomyopathy, restrictive cardiomyopathy, infectious or inflammatory conditions of the heart or pericardial disease. As 
such, there are no published data on the use of anatomic models in these conditions.

\section{Cardiac trauma}

Blunt cardiac trauma may result in myocardial contusion with more severe blunt or penetrating trauma often resulting in exsanguination, pericardial tamponade or death. Treatable serious cardiac trauma requires resuscitation and emergent surgical management, thereby precluding the use of a 3D printed anatomic model due to the necessary segmentation and printing time.

\section{Conclusion}

This document provides initial appropriateness recommendations for 3D printing in adult cardiac pathology. Ratings used available clinical evidence primarily from structured searches plus expert opinion when there is a paucity of evidence, recognizing that sparse data mandates that individual opinions can weigh heavily on appropriateness recommendations [148]. AUC as defined in the United States by the Centers of Medicare and Medicaid include multidisciplinary society input [149]. One limitation of the current SIG recommendations is that additional expert opinion, in this case from practicing cardiologists and cardiac surgeons, is lacking. This is an important gap, particularly as AUC and related documents move towards the peer-review literature [150, 151]. Adoption of common clinical standards regarding appropriate use, information and material management, and quality control are needed to ensure the greatest possible clinical benefit from 3D printing. It is anticipated that this consensus guideline document, created by the members of the RSNA 3D printing Special Interest Group, will provide a reference for clinical standards of 3D printing. The document will be periodically refined, based on expanding clinical applications and growing medical literature.

\section{Supplementary information}

Supplementary information accompanies this paper at https://doi.org/10. 1186/s41205-020-00078-1.

Additional file 1:. Supporting evidence obtained through structured PubMed searches. For each category, from the pool of total results, the number of publications considered "Relevant results" was curated by consensus between physicians with expertise in 3D printing and cardiovascular care. Relevant publications which were not retrieved by the structured PubMed search were manually entered into the appropriate categories and indicated accordingly.

Additional file 2:. Grading of each included study with a strength of evidence assessment according to ACR Appropriateness Criteria Evidence Document [144]. Studies were categorized as either primarily diagnostic (Dx), therapeutic $(T x)$, or both $(D x$ and $T x)$ along with a designation of observational, experimental, or review/other category. The review/other category is designated for studies that did not meet the definitions the ACR Evidence Document [144] for observational or experimental studies.

\section{Abbreviations}

RSNA: Radiological Society of North America; SIG: Special Interest Group; AUC: Appropriate use criteria; LVAD: Left ventricular assistive device

\section{Acknowledgements}

We acknowledge the inciteful collaboration of the Radiological Society of North America 3D printing Special Interest Group in the development of this document. The article processing charge for this publication has been funded generously by an unrestricted educational grant from Stratasys.

\section{Authors' contributions}

Every author listed above has been involved in design, data collection, interpretation, as well as manuscript drafting and editing. All authors read and approved the final manuscript.

\section{Funding}

No funding sources to declare for this study.

\section{Availability of data and materials}

The datasets used and/or analyzed during the current study are available from the corresponding author on reasonable request.

Ethics approval and consent to participate

Not applicable.

\section{Consent for publication}

Not applicable.

\section{Competing interests}

The authors declare that they have no competing interests related to this work. None of the authors has any relationship with Stratasys. Competing Interests not related to this work:

JM: Healthcare Advisory Committee member: Hewlett Packard; Sponsored speaker: Materialise; Consultant, speaker: Medtronic; Consultant, speaker: Merit Health; Consultant: Izimed; Sponsored travel education meeting: Stryker NW: In-kind research support: Stratasys; Consultant: GE Healthcare

FR: Director of Medical Affairs: Imagia

AS: Speaker: Siemens

\section{Author details}

'Department of Radiology, University of Cincinnati Medical Center, Cincinnati, OH, USA. ${ }^{2}$ Mallinckrodt Institute of Radiology, Washington University School of Medicine, Saint Louis, MO, USA. ${ }^{3}$ King Faisal Specialist Hospital and Research Centre, Riyadh, Saudi Arabia. ${ }^{4}$ Department of Radiology and The Ottawa Hospital Research Institute, University of Ottawa, Ottawa, ON, Canada. ${ }^{5}$ Boston Children's Hospital, Boston, MA, USA. ${ }^{6}$ Sidney Kimmel Medical College, Thomas Jefferson University, Philadelphia, PA, USA. 73D Medical Applications Center, Walter Reed National Military Medical Center, Washington, DC, USA. ${ }^{8}$ Department of Radiology, Mayo Clinic, Rochester, MN, USA. ${ }^{9}$ Rady Children's Hospital, San Diego, CA, USA.

${ }^{10}$ Intermountain Healthcare, South Jordan, UT, USA. ${ }^{11}$ Department of Radiology, Montefiore Medical Center, Bronx, NY, USA.

Received: 13 January 2020 Accepted: 4 September 2020

Published online: 23 September 2020

\section{References}

1. Chepelev L, Wake N, Ryan J, et al. Radiological Society of North America (RSNA) 3D printing Special Interest Group (SIG): guidelines for medical 3D printing and appropriateness for clinical scenarios. 3D Print Med. 2018;4(1):11.

2. ACR Appropriateness Criteria (2018) American college of radiology.https:// www.acr.org/Clinical-Resources/ACR-Appropriateness-Criteria. Accessed 2 Dec 2019.

3. Cohn LH. Cardiac Surgery in the Adult. New York: McGraw Hill Education; 2018.

4. Libby P, Braunwald E. Braunwald's heart disease: A textbook of cardiovascular medicine. Philadelphia: Saunders/Elsevier; 2008.

5. Faroogi KM, Cooper C, Chelliah A, et al. 3D Printing and Heart Failure: The Present and the Future. JACC Heart Fail. 2019;7(2):132-42. 
6. Uccheddu F, Gallo M, Nocerino E, et al. Cardiovascular interventions planning through a three-dimensional printing patient-specific approach. J Cardiovasc Med (Hagerstown). 2019;20(9):584-96.

7. Oliveira-Santos M, Oliveira-Santos E, Goncalves L, Silva MJ. Cardiovascular Three-Dimensional Printing in Non-Congenital Percutaneous Interventions. Heart Lung Circ. 2019;28(10):1525-34.

8. Birbara NS, Otton JM, Pather N. 3D Modelling and Printing Technology to Produce Patient-Specific 3D Models. Heart Lung Circ. 2019;28(2):302-13.

9. Gardin C, Ferroni L, Latremouille C, Chachques JC, Mitrečić D, Zavan B. Recent Applications of Three Dimensional Printing in Cardiovascular Medicine. Cells. 2020;9(3):742. Published 2020 Mar 17. https://doi.org/10. 3390/cells9030742.

10. Tuncay V, van Ooijen PMA. 3D printing for heart valve disease: a systematic review. Eur Radiol Exp. 2019;3(1):9.

11. Boll LFC, Rodrigues GO, Rodrigues CG, Bertollo FL, Irigoyen MC, Goldmeier S. Using a 3D printer in cardiac valve surgery: a systematic review. Rev Assoc Med Bras (1992). 2019;65(6):818-24.

12. Vukicevic M, Mosadegh B, Min JK, Little SH. Cardiac 3D Printing and its Future Directions. JACC Cardiovasc Imaging. 2017;10(2):171-84.

13. Giannopoulos AA, Steigner ML, George E, et al. Cardiothoracic Applications of 3-dimensional Printing. J Thorac Imaging. 2016;31(5):253-72.

14. Garner KH, Singla DK. 3D modeling: a future of cardiovascular medicine (1). Can J Physiol Pharmacol. 2019;97(4):277-86.

15. Bartel T, Rivard A, Jimenez A, Mestres CA, Muller S. Medical threedimensional printing opens up new opportunities in cardiology and cardiac surgery. Eur Heart J. 2018;39(15):1246-54.

16. Randles A, Frakes DH, Leopold JA. Computational Fluid Dynamics and Additive Manufacturing to Diagnose and Treat Cardiovascular Disease. Trends Biotechnol. 2017;35(11):1049-61.

17. Shi D, Liu K, Zhang X, Liao H, Chen X. Applications of three-dimensional printing technology in the cardiovascular field. Intern Emerg Med. 2015; 10(7):769-80.

18. Ganguli A, Pagan-Diaz GJ, Grant L, et al. 3D printing for preoperative planning and surgical training: a review. Biomed Microdevices. 2018;20(3):65.

19. Ferrari E, Gallo M, Wang C, et al. Three-dimensional printing in adult cardiovascular medicine for surgical and transcatheter procedural planning, teaching and technological innovation. Interact Cardiovasc Thorac Surg. 2020:30(2):203-14. https://doi.org/10.1093/icvts/ivz250.

20. Paulsen MJ, Kasinpila P, Imbrie-Moore AM, et al. Modeling conduit choice for valve-sparing aortic root replacement on biomechanics with a 3-dimensionalprinted heart simulator. J Thorac Cardiovasc Surg. 2019;158(2):392-403.

21. Ahn CB, Lee $\mathrm{Sl}$, Choi $\mathrm{CH}$, et al. Feasibility of a 3D Printed Patient-Specific Model System to Determine Hemodynamic Energy Delivery During Extracorporeal Circulation. ASAIO J. 2018;64(3):309-17.

22. Modi BN, Ryan M, Chattersingh A, et al. Optimal Application of Fractional Flow Reserve to Assess Serial Coronary Artery Disease: A 3D-Printed Experimental Study With Clinical Validation. J Am Heart Assoc. 2018;7(20): e010279.

23. Yang Y, Liu X, Xia Y, et al. Impact of spatial characteristics in the left stenotic coronary artery on the hemodynamics and visualization of $3 \mathrm{D}$ replica models. Sci Rep. 2017;7(1):15452.

24. Sommer K, Izzo RL, Shepard L, et al. Design Optimization for Accurate Flow Simulations in 3D Printed Vascular Phantoms Derived from Computed Tomography Angiography. Proc SPIE Int Soc Opt Eng. 2017;10138:101380R. https://doi.org/10.1117/12.2253711.

25. Shepard L, Sommer K, Izzo R, et al. Initial Simulated FFR Investigation Using Flow Measurements in Patient-specific 3D Printed Coronary Phantoms. Proc SPIE Int Soc Opt Eng. 2017;10138:101380S. https://doi.org/10.1117/12. 2253889.

26. Shepard LM, Sommer KN, Angel E, et al. Initial evaluation of threedimensionally printed patient-specific coronary phantoms for CT-FFR software validation. J Med Imaging (Bellingham). 2019;6(2):021603.

27. Sommer KN, Shepard L, Karkhanis NV, et al. 3D Printed Cardiovascular Patient Specific Phantoms Used for Clinical Validation of a CT-derived FFR Diagnostic Software. Proc SPIE Int Soc Opt Eng. 2018;10578:105780J. https:// doi.org/10.1117/12.2292736.

28. Sun Z, Jansen S. Personalized 3D printed coronary models in coronary stenting. Quant Imaging Med Surg. 2019;9(8):1356-67.

29. Lee M, Moharem-Elgamal S, Beckingham R, et al. Evaluating 3D-printed models of coronary anomalies: a survey among clinicians and researchers at a university hospital in the UK. BMJ Open. 2019;9(3):e025227.
30. Oliveira-Santos M, Oliveira Santos E, Marinho AV, et al. Patient-specific 3D printing simulation to guide complex coronary intervention. Rev Port Cardiol. 2018;37(6):541 e541-4.

31. Salavitabar A, Chelliah A, Kalfa D, Crystal MA. When a coronary artery fistula is not simply a fistula: Using multimodality imaging to demonstrate an unusual embryologic remnant. J Thorac Cardiovasc Surg. 2018;156(1):358-62.

32. Wang $H$, Liu J, Zheng $X$, et al. Three-dimensional virtual surgery models for percutaneous coronary intervention $(\mathrm{PCl})$ optimization strategies. Sci Rep. 2015;5:10945

33. Misra A, Walters HL, Kobayashi D. Utilisation of a three-dimensional printed model for the management of coronary-pulmonary artery fistula from left main coronary artery. Cardiol Young. 2019;29(3):431-4.

34. Aroney N, Lau K, Daniele L, Burstow D, Walters D. Three-dimensional printing: to guide management of a right coronary artery to left ventricular fistula. Eur Heart J Cardiovasc Imaging. 2018;19(3):268.

35. Velasco Forte MN, Byrne N, Valverde Perez I, et al. 3D printed models in patients with coronary artery fistulae: anatomical assessment and interventional planning. Eurolntervention. 2017;13(9):e1080-3.

36. Sedaghat A, Wolpers AC, Menne M, et al. Percutaneous treatment of a saccular coronary artery aneurysm using multimodal imaging and rapid prototyping. Eur Heart J. 2018;39(46):4125.

37. Lazkani M, Bashir F, Brady K, Pophal S, Morris M, Pershad A. Postinfarct VSD management using 3D computer printing assisted percutaneous closure. Indian Heart J. 2015;67(6):581-5.

38. Mohamed E, Telila T, Osaki S, Jacobson K. Percutaneous closure of left ventricle pseudoaneurysm using 3D printed heart model for procedure planning: A novel approach. Catheter Cardiovasc Interv. 2019;94(6):874-7. https://doi.org/10.1002/ccd.28405.

39. So $C Y$, Fan $Y$, Wu EB, Lee AP. $3 D$ Anticipating coronary obstruction with threedimensional printing in transcatheter aortic valve implantation. Eurolntervention. 2020;15(16):1424-5. https//doi.org/10.4244/EJJ-D-19-00609.

40. Bompotis G, Meletidou M, Karakanas A, et al. Transcatheter Aortic Valve Implantation using 3-D printing modeling assistance. A single-center experience. Hellenic J Cardiol. 2020;61(2):131-2. https://doi.org/10.1016/j.hjc. 2019.01.012

41. Yamawaki M, Obama K, Sasuga S, et al. Underfilled Balloon-Expandable Transcatheter Aortic Valve Implantation With Ad Hoc Post-Dilation- Pulsatile Flow Simulation Using a Patient-Specific Three-Dimensional Printing Model. Circ J. 2019;83(2):461-70.

42. Gomes EN, Dias RR, Rocha BA, et al. Use of 3D Printing in Preoperative Planning and Training for Aortic Endovascular Repair and Aortic Valve Disease. Braz J Cardiovasc Surg. 2018;33(5):490-5

43. Hosny A, Dilley JD, Kelil T, et al. Pre-procedural fit-testing of TAVR valves using parametric modeling and 3D printing. J Cardiovasc Comput Tomogr. 2019;13(1):21-30.

44. Hatoum H, Dollery J, Lilly SM, Crestanello JA, Dasi LP. Sinus Hemodynamics Variation with Tilted Transcatheter Aortic Valve Deployments. Ann Biomed Eng. 2019:47(1):75-84.

45. Harb SC, Xu B, Klatte R, Griffin BP, Rodriquez LL. Haemodynamic Assessment of Severe Aortic Stenosis Using a Three-Dimensional (3D) Printed Model Incorporating a Flow Circuit. Heart Lung Circ. 2018;27(11):e105-7.

46. Faletti R, Gatti M, Cosentino A, et al. 3D printing of the aortic annulus based on cardiovascular computed tomography: Preliminary experience in preprocedural planning for aortic valve sizing. J Cardiovasc Comput Tomogr. 2018:12(5):391-7.

47. Shirakawa T, Yoshitatsu M, Koyama Y, Mizoguchi H, Toda K, Sawa Y. 3Dprinted aortic stenosis model with fragile and crushable calcifications for off-the-job training and surgical simulation. Multimed Man Cardiothorac Surg. 2018;2018. Published 2018 May 14. https://doi.org/10.1510/mmcts. 2018.01863.

48. Zhou X, Vannan MA, Qian Z. 3D printing for trans-catheter aortic valve replacement: Integrating anatomy and physiology to plan, predict and optimize procedural outcomes. Int J Cardiol. 2018;258:334-5.

49. Alkhouli M, Sengupta PP. 3-Dimensional-Printed Models for TAVR Planning: Why Guess When You Can See? JACC Cardiovasc Imaging. 2017;10(7):732-4.

50. Hernandez-Enriquez M, Brugaletta S, Andreu D, et al. Three-dimensional printing of an aortic model for transcatheter aortic valve implantation: possible clinical applications. Int J Cardiovasc Imaging. 2017;33(2):283-5.

51. Fujita B, Kutting M, Scholtz $\mathrm{S}$, et al. Development of an algorithm to plan and simulate a new interventional procedure. Interact Cardiovasc Thorac Surg. 2015;21(1):87-95. 
52. Fujita B, Kutting M, Seiffert $M$, et al. Calcium distribution patterns of the aortic valve as a risk factor for the need of permanent pacemaker implantation after transcatheter aortic valve implantation. Eur Heart J Cardiovasc Imaging. 2016;17(12):1385-93.

53. Fujita T, Saito N, Minakata K, Imai M, Yamazaki K, Kimura T. Transfemoral transcatheter aortic valve implantation in the presence of a mechanical mitral valve prosthesis using a dedicated TAVI guidewire: utility of a patient-specific three-dimensional heart model. Cardiovasc Interv Ther. 2017;32(3):308-11.

54. Jung Jl, Koh YS, Chang K. 3D Printing Model before and after Transcatheter Aortic Valve Implantation for a Better Understanding of the Anatomy of Aortic Root. Korean Circ J. 2016;46(4):588-9.

55. Gallo M, D'Onofrio A, Tarantini G, Nocerino E, Remondino F, Gerosa G. 3Dprinting model for complex aortic transcatheter valve treatment. Int J Cardiol. 2016;210:139-40

56. Ripley B, Kelil T, Cheezum MK, et al. 3D printing based on cardiac CT assists anatomic visualization prior to transcatheter aortic valve replacement. J Cardiovasc Comput Tomogr. 2016;10(1):28-36.

57. Maragiannis D, Jackson MS, Igo SR, et al. Replicating Patient-Specific Severe Aortic Valve Stenosis With Functional 3D Modeling. Circ Cardiovasc Imaging. 2015;8(10):e003626.

58. Schmauss D, Schmitz C, Bigdeli AK, et al. Three-dimensional printing of models for preoperative planning and simulation of transcatheter valve replacement. Ann Thorac Surg. 2012;93(2):e31-3.

59. Rotman OM, Kovarovic B, Sadasivan C, Gruberg L, Lieber BB, Bluestein D. Realistic Vascular Replicator for TAVR Procedures. Cardiovasc Eng Technol. 2018;9(3):339-50.

60. Benke K, Barabas Jl, Daroczi L, et al. Routine aortic valve replacement followed by a myriad of complications: role of $3 \mathrm{D}$ printing in a difficult cardiac surgical case. J Thorac Dis. 2017;9(11):E1021-4.

61. Jelenc M, Jelenc B, Knezevic I, Klokocovnik T. New graft sizing rings for aortic valve reimplantation procedures. Interact Cardiovasc Thorac Surg. 2018;26(1):1-3.

62. Sodian R, Schmauss D, Markert M, et al. Three-dimensional printing creates models for surgical planning of aortic valve replacement after previous coronary bypass grafting. Ann Thorac Surg. 2008;85(6):2105-8.

63. Baribeau Y, Sharkey A, Mahmood E, et al. Three-Dimensional Printing and Transesophageal Echocardiographic Imaging of Patient-Specific Mitral Valve Models in a Pulsatile Phantom Model. J Cardiothorac Vasc Anesth. 2019.

64. Ginty OK, Moore JT, Eskandari M, et al. Dynamic, patient-specific mitral valve modelling for planning transcatheter repairs. Int J Comput Assist Radiol Surg. 2019;14(7):1227-35.

65. Kohli K, Wei ZA, Yoganathan AP, Oshinski JN, Leipsic J, Blanke P. Transcatheter Mitral Valve Planning and the Neo-LVOT: Utilization of Virtual Simulation Models and 3D Printing. Curr Treat Options Cardiovasc Med. 2018;20(12):99.

66. Ferrari E, Biasco L, Faletra F, et al. Tiara Valve Implantation in a Patient With Previously Implanted Mono-disk Mechanical Aortic Prosthesis. Semin Thorac Cardiovasc Surg. 2018;30(2):160-3.

67. Bagur R, Cheung A, Chu MWA, Kiaii B. 3-Dimensional-Printed Model for Planning Transcatheter Mitral Valve Replacement. JACC Cardiovasc Interv. 2018;11(8):812-3.

68. El Sabbagh A, Eleid MF, Matsumoto JM, et al. Three-dimensional prototyping for procedural simulation of transcatheter mitral valve replacement in patients with mitral annular calcification. Catheter Cardiovasc Interv. 2018;92(7):E537-49.

69. Wang DD, Eng MH, Greenbaum AB, et al. Validating a prediction modeling tool for left ventricular outflow tract (LVOT) obstruction after transcatheter mitral valve replacement (TMVR). Catheter Cardiovasc Interv. 2018;92(2):379-87.

70. Ginty O, Moore J, Peters T, Bainbridge D. Modeling Patient-Specific Deformable Mitral Valves. J Cardiothorac Vasc Anesth. 2018;32(3):1368-73.

71. Scanlan $A B$, Nguyen $A V$, llina $A$, et al. Comparison of $3 D$ EchocardiogramDerived 3D Printed Valve Models to Molded Models for Simulated Repair of Pediatric Atrioventricular Valves. Pediatr Cardiol. 2018;39(3):538-47.

72. Zhu Y, Liu J, Wang L, et al. Preliminary study of the application of transthoracic echocardiography-guided three-dimensional printing for the assessment of structural heart disease. Echocardiography. 2017; 34(12):1903-8

73. Dahle G, Rein KA, Fiane AE. Single centre experience with transapical transcatheter mitral valve implantation. Interact Cardiovasc Thorac Surg. 2017;25(2):177-84
74. Vukicevic M, Puperi DS, Jane Grande-Allen K, Little SH. 3D Printed Modeling of the Mitral Valve for Catheter-Based Structural Interventions. Ann Biomed Eng. 2017;45(2):508-19.

75. Mashari A, Knio Z, Jeganathan J, et al. Hemodynamic Testing of PatientSpecific Mitral Valves Using a Pulse Duplicator: A Clinical Application of Three-Dimensional Printing. J Cardiothorac Vasc Anesth. 2016;30(5):1278-85.

76. Little SH, Vukicevic M, Avenatti E, Ramchandani M, Barker CM. 3D Printed Modeling for Patient-Specific Mitral Valve Intervention: Repair With a Clip and a Plug. JACC Cardiovasc Interv. 2016;9(9):973-5.

77. Izzo RL, O'Hara RP, Iyer V, et al. 3D Printed Cardiac Phantom for Procedural Planning of a Transcatheter Native Mitral Valve Replacement. Proc SPIE Int Soc Opt Eng. 2016;9789:978908. https://doi.org/10.1117/12.2216952.

78. Mahmood F, Owais K, Taylor C, et al. Three-dimensional printing of mitral valve using echocardiographic data. JACC Cardiovasc Imaging. 2015;8(2):227-9. https://doi.org/10.1016/j.jcmg.2014.06.02.

79. Owais K, Pal A, Matyal R, et al. Three-dimensional printing of the mitral annulus using echocardiographic data: science fiction or in the operating room next door? J Cardiothorac Vasc Anesth. 2014;28(5):1393-6.

80. Witschey WR, Pouch AM, McGarvey JR, et al. Three-dimensional ultrasoundderived physical mitral valve modeling. Ann Thorac Surg. 2014;98(2):691-4.

81. Hascoet S, Smolka G, Bagate F, et al. Multimodality imaging guidance for percutaneous paravalvular leak closure: Insights from the multi-centre FFPP register. Arch Cardiovasc Dis. 2018;111(6-7):421-31.

82. Engelhardt S, Sauerzapf S, Preim B, Karck M, Wolf I, De Simone R. Flexible and comprehensive patient-specific mitral valve silicone models with chordae tendineae made from 3D-printable molds. Int J Comput Assist Radiol Surg. 2019;14(7):1177-86. https://doi.org/10.1007/s11548-019-01971-9.

83. Theodoropoulos KC, Papachristidis A, Fonseca T, Reiken J, Monaghan MJ. Understanding the anatomy of a perforated mitral valve: From 2D echocardiography to 3D printing. Hellenic J Cardiol. 2018.

84. Daemen JHT, Heuts S, Olsthoorn JR, Maessen JG, Sardari NP. Mitral valve modelling and three-dimensional printing for planning and simulation of mitral valve repair. Eur J Cardiothorac Surg. 2019;55(3):543-51.

85. Ginty OK, Moore JM, Xu Y, et al. Dynamic Patient-Specific ThreeDimensional Simulation of Mitral Repair: Can We Practice Mitral Repair Preoperatively? Innovations (Phila). 2018:13(1):11-22.

86. Yamada T, Osako M, Uchimuro T, et al. Three-Dimensional Printing of LifeLike Models for Simulation and Training of Minimally Invasive Cardiac Surgery. Innovations (Phila). 2017;12(6):459-65.

87. Premyodhin N, Mandair D, Ferng AS, et al. 3D printed mitral valve models: affordable simulation for robotic mitral valve repair. Interact Cardiovasc Thorac Surg. 2018;26(1):71-6.

88. Sardari Nia P, Heuts S, Daemen J, et al. Preoperative planning with threedimensional reconstruction of patient's anatomy, rapid prototyping and simulation for endoscopic mitral valve repair. Interact Cardiovasc Thorac Surg. 2017;24(2):163-8.

89. Dankowski R, Baszko A, Sutherland M, et al. 3D heart model printing for preparation of percutaneous structural interventions: description of the technology and case report. Kardiol Pol. 2014;72(6):546-51.

90. Muraru D, Hahn RT, Soliman Ol, Faletra FF, Basso C, Badano LP. 3Dimensional Echocardiography in Imaging the Tricuspid Valve. JACC Cardiovasc Imaging. 2019;12(3):500-15.

91. Muraru D, Veronesi F, Maddalozzo A, et al. 3D printing of normal and pathologic tricuspid valves from transthoracic 3D echocardiography data sets. Eur Heart J Cardiovasc Imaging. 2017;18(7):802-8.

92. Wang DD, Lee JC, O'Neill BP, O'Neill WW. Multimodality Imaging of the Tricuspid Valve for Assessment and Guidance of Transcatheter Repair. Interv Cardiol Clin. 2018;7(3):379-86.

93. Harb SC, Rodriguez LL, Svensson LG, et al. Pitfalls and Pearls for 3Dimensional Printing of the Tricuspid Valve in the Procedural Planning of Percutaneous Transcatheter Therapies. JACC Cardiovasc Imaging. 2018; 11(10):1531-4

94. Navia JL, Kapadia S, Elgharably H, et al. First-in-Human Implantations of the NaviGate Bioprosthesis in a Severely Dilated Tricuspid Annulus and in a Failed Tricuspid Annuloplasty Ring. Circ Cardiovasc Interv. 2017;10(12):e005840.

95. O'Neill B, Wang DD, Pantelic M, et al. Transcatheter caval valve implantation using multimodality imaging: roles of TEE, $C T$, and $3 D$ printing. JACC Cardiovasc Imaging. 2015;8(2):221-5.

96. Valverde I, Sarnago F, Prieto R, Zunzunegui JL. Three-dimensional printing in vitro simulation of percutaneous pulmonary valve implantation in large right ventricular outflow tract. Eur Heart J. 2017;38(16):1262-3. 
97. Schievano S, Migliavacca F, Coats L, et al. Percutaneous pulmonary valve implantation based on rapid prototyping of right ventricular outflow tract and pulmonary trunk from MR data. Radiology. 2007;242(2):490-7.

98. Armillotta A, Bonhoeffer P, Dubini G, et al. Use of rapid prototyping models in the planning of percutaneous pulmonary valved stent implantation. Proc Inst Mech Eng H. 2007;221(4):407-16.

99. Knecht S, Brantner P, Cattin P, Tobler D, Kuhne M, Sticherling C. State-of-the-art multimodality approach to assist ablations in complex anatomies-From 3D printing to virtual reality. Pacing Clin Electrophysiol. 2019;42(1):101-3.

100. Lodzinski P, Balsam P, Peller M, Gawalko M, Opolski G, Grabowski M. Threedimensional print facilitated ventricular tachycardia ablation in patient with corrected congenital heart disease. Cardiol J. 2017;24(5):584-5.

101. Bauch T, Vijayaraman P, Dandamudi G, Ellenbogen K. Three-Dimensional Printing for In Vivo Visualization of His Bundle Pacing Leads. Am J Cardiol. 2015;116(3):485-6.

102. Seckeler MD, White SC, Klewer SE, Ott P. Transjugular Transseptal Approach for Left Ventricular Pacing Lead in an Adult With Criss-Cross Heart. JACC Clin Electrophysiol. 2019;5(8):998-9.

103. Liddy S, McQuade C, Walsh KP, Loo B, Buckley O. The Assessment of Cardiac Masses by Cardiac CT and CMR Including Pre-op 3D Reconstruction and Planning. Curr Cardiol Rep. 2019;21(9):103.

104. Young PM, Foley TA, Araoz PA, Williamson EE. Computed Tomography Imaging of Cardiac Masses. Radiol Clin North Am. 2019;57(1):75-84.

105. Riggs KW, Dsouza G, Broderick JT, Moore RA, Morales DLS. 3D-printed models optimize preoperative planning for pediatric cardiac tumor debulking. Transl Pediatr. 2018;7(3):196-202.

106. Golab A, Slojewski M, Brykczynski M, et al. Three-Dimensional Printing as an Interdisciplinary Communication Tool: Preparing for Removal of a Giant Renal Tumor and Atrium Neoplastic Mass. Heart Surg Forum. 2016;19(4): E185-6.

107. Al Jabbari O, Abu Saleh WK, Patel AP, Igo SR, Reardon MJ. Use of threedimensional models to assist in the resection of malignant cardiac tumors. J Card Surg. 2016;31(9):581-3.

108. Son KH, Kim KW, Ahn CB, et al. Surgical Planning by 3D Printing for Primary Cardiac Schwannoma Resection. Yonsei Med J. 2015;56(6):1735-7.

109. Schmauss D, Gerber N, Sodian R. Three-dimensional printing of models for surgical planning in patients with primary cardiac tumors. J Thorac Cardiovasc Surg. 2013;145(5):1407-8.

110. Jacobs S, Grunert R, Mohr FW, Falk V. 3D-Imaging of cardiac structures using 3D heart models for planning in heart surgery: a preliminary study. Interact Cardiovasc Thorac Surg. 2008;7(1):6-9.

111. Yoo JS, Reddy YNV, Kim KH. Heart transplantation for dextrocardia: preoperative planning using 3D printing. Eur Heart J Cardiovasc Imaging. 2020; 21(3):346. https://doi.org/10.1093/ehjci/jez263.

112. Thaker R, Araujo-Gutierrez R, Marcos-Abdala HG, Agrawal T, Fida N, Kassi M. Innovative Modeling Techniques and 3D Printing in Patients with Left Ventricular Assist Devices: A Bridge from Bench to Clinical Practice. J Clin Med. 2019;8(5):635

113. Miller J, Billadello J, Simon-Lee R, et al. 3D PRINTING FOR PREOPERATIVE PLANNING AND SURGICAL SIMULATION OF VAD IMPLANTATION IN A FAIL ING RIGHT SYSTEMIC VENTRICLE. J Am College Cardiol. 2018;71(11 Supplement):A545

114. Faroogi KM, Saeed O, Zaidi A, et al. 3D Printing to Guide Ventricular Assist Device Placement in Adults With Congenital Heart Disease and Heart Failure. JACC Heart Fail. 2016;4(4):301-11.

115. Fan Y, Kwok KW, Zhang Y, Cheung GS, Chan AK, Lee AP. Three-Dimensional Printing for Planning Occlusion Procedure for a Double-Lobed Left Atrial Appendage. Circ Cardiovasc Interv. 2016;9(3):e003561.

116. Fan Y, Yang F, Cheung GS, et al. Device Sizing Guided by Echocardiography-Based Three-Dimensional Printing Is Associated with Superior Outcome after Percutaneous Left Atrial Appendage Occlusion. J Am Soc Echocardiogr. 2019;32(6):708-19 e701.

117. Morcos R, Al Taii H, Bansal P, et al. Accuracy of Commonly-Used Imaging Modalities in Assessing Left Atrial Appendage for Interventional Closure: Review Article. J Clin Med. 2018;7(11):441.

118. Hell MM, Achenbach S, Yoo IS, et al. 3D printing for sizing left atrial appendage closure device: head-to-head comparison with computed tomography and transoesophageal echocardiography. Eurolntervention. 2017;13(10):1234-41.

119. Li H. Qingyao, Bingshen, et al. Application of 3D printing technology to left atrial appendage occlusion. Int J Cardiol. 2017;231:258-63.
120. Goitein O, Fink N, Guetta V, et al. Printed MDCT 3D models for prediction of left atrial appendage (LAA) occluder device size: a feasibility study. Eurolntervention. 2017;13(9):e1076-9.

121. Conti M, Marconi S, Muscogiuri G, et al. Left atrial appendage closure guided by 3D computed tomography printing technology: A case control study. J Cardiovasc Comput Tomogr. 2019;13(6):336-9. https://doi.org/10. 1016/j.jcct.2018.10.024

122. Litwinowicz R, Witowski J, Sitkowski M, et al. Applications of low-cost 3D printing in left atrial appendage closure using epicardial approaches - initial clinical experience. Kardiochir Torakochirurgia Pol. 2018;15(2):135-40.

123. Hachulla AL, Noble S, Guglielmi G, Agulleiro D, Muller H, Vallee JP. 3Dprinted heart model to guide LAA closure: useful in clinical practice? Eur Radiol. 2019:29(1):251-8.

124. Iriart X, Ciobotaru V, Martin C, et al. Role of cardiac imaging and threedimensional printing in percutaneous appendage closure. Arch Cardiovasc Dis. 2018;111(6-7):411-20.

125. Ciobotaru V, Combes N, Martin CA, et al. Left atrial appendage occlusion simulation based on three-dimensional printing: new insights into outcome and technique. Eurolntervention. 2018;14(2):176-84.

126. Wang DD, Eng M, Kupsky D, et al. Application of 3-Dimensional Computed Tomographic Image Guidance to WATCHMAN Implantation and Impact on Early Operator Learning Curve: Single-Center Experience. JACC CardiovasC Interv. 2016;9(22):2329-40.

127. Obasare E, Mainigi SK, Morris DL, et al. CT based $3 D$ printing is superior to transesophageal echocardiography for pre-procedure planning in left atrial appendage device closure. Int J Cardiovasc Imaging. 2018;34(5):821-31.

128. Khalili H, Gentry RE, Stevens MA, et al. Rapid and Affordable 3-Dimensional Prototyping for Left Atrial Appendage Closure Planning. Circ Cardiovasc Interv. 2017;10(2):e004710.

129. Liu P, Liu R, Zhang Y, Liu Y, Tang X, Cheng Y. The Value of 3D Printing Models of Left Atrial Appendage Using Real-Time 3D Transesophageal Echocardiographic Data in Left Atrial Appendage Occlusion: Applications toward an Era of Truly Personalized Medicine. Cardiology. 2016;135(4):255-61.

130. Pellegrino PL, Fassini G. M DIB, Tondo C. Left Atrial Appendage Closure Guided by 3D Printed Cardiac Reconstruction: Emerging Directions and Future Trends. J Cardiovasc Electrophysiol. 2016;27(6):768-71.

131. Otton JM, Spina R, Sulas R, et al. Left Atrial Appendage Closure Guided by Personalized 3D-Printed Cardiac Reconstruction. JACC Cardiovasc Interv. 2015;8(7):1004-6.

132. Song $H$, Zhou $Q$, Zhang $L$, et al. Evaluating the morphology of the left atrial appendage by a transesophageal echocardiographic 3-dimensional printed model. Medicine (Baltimore). 2017;96(38):e7865.

133. Andrushchuk U, Adzintsou V, Nevyglas A, Model H. Virtual and real septal myectomy using 3-dimensional printed models. Interact Cardiovasc Thorac Surg. 2018;26(5):881-2

134. Andrushchuk U, Adzintsou V, Niavyhlas A, Model H, Ostrovsky Y. Early results of optimal septal myectomy using 3-dimensional printed models. Kardiochir Torakochirurgia Pol. 2019;16(2):74-80.

135. Sun X, Zhang H, Zhu K, Wang C. Curved section modeling-based three-dimensional printing for guiding septal myectomy. J Thorac Dis. 2018;10(7):E535-7.

136. Hermsen JL, Yang R, Burke TM, et al. Development of a 3-D printing-based cardiac surgical simulation curriculum to teach septal myectomy. J Thorac Cardiovasc Surg. 2018;156(3):1139-48 e1133.

137. Guo HC, Wang Y, Dai J, Ren CW, Li JH, Lai YQ. Application of 3D printing in the surgical planning of hypertrophic obstructive cardiomyopathy and physicianpatient communication: a preliminary study. J Thorac Dis. 2018;10(2):867-73.

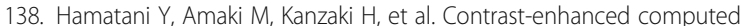
tomography with myocardial three-dimensional printing can guide treatment in symptomatic hypertrophic obstructive cardiomyopathy. ESC Heart Fail. 2017:4(4):665-9.

139. Parachuri VR, Adhyapak SM. The case for surgical myectomy in hypertrophic cardiomyopathy: Is strategic planning the key to success? J Thorac Cardiovasc Surg. 2017;154(5):1687-8.

140. Yang DH, Kang JW, Kim N, Song JK, Lee JW, Lim TH. Myocardial 3Dimensional Printing for Septal Myectomy Guidance in a Patient With Obstructive Hypertrophic Cardiomyopathy. Circulation. 2015;132(4):300-1.

141. Johnston NF, Prendiville T, McMahon CJ. 3D printing of severe hypertrophic cardiomyopathy in a child with Rasopathy. Ir J Med Sci. 2018;187(1):55-7.

142. Veselka J, Adla T, Adlova R, Bartel T. Three-Dimensional Heart Printing for Planning of Septal Reduction Therapy in Patients with Hypertrophic Obstructive Cardiomyopathy. Int J Angiol. 2018;27(3):165-6. 
143. Hermsen JL, Burke TM, Seslar SP, et al. Scan, plan, print, practice, perform: Development and use of a patient-specific 3-dimensional printed model in adult cardiac surgery. J Thorac Cardiovasc Surg. 2017;153(1):132-40.

144. ACR Appropriateness Criteria ${ }^{\circledR}$ Evidence Document. https:/www.acr.org/-/ media/ACR/Files/Appropriateness-Criteria/EvidenceTableDevelopment.pdf. Accessed December 10, 2019

145. Anderson JL, Morrow DA. Acute Myocardial Infarction. N Engl J Med. 2017; 376(21):2053-64.

146. Sandhu AT, Woo YJ, Khush KK. Optimizing the Use of Heart Transplant in the United States. JAMA. 2019;322(18):1772-4.

147. Holmes DR Jr, Doshi SK, Kar S, et al. Left Atrial Appendage Closure as an Alternative to Warfarin for Stroke Prevention in Atrial Fibrillation: A PatientLevel Meta-Analysis. J Am Coll Cardiol. 2015;65(24):2614-23.

148. Rybicki FJ. Scholarship in the Appropriateness Criteria((R)) Process and Updates on Gaps and Harmonization. J Am Coll Radiol. 2017:14(11S):S381-2.

149. Rybicki FJ. Timelines and Case Use Metrics for the ACR Appropriateness Criteria((R)). J Am Coll Radiol. 2018;15(11S):S215-6.

150. Rybicki FJ. The Role of the ACR Appropriateness Criteria in the Medical Literature. J Am Coll Radiol. 2018;15(5S):S1.

151. Rybicki FJ. Message From Frank J. Rybicki, MD, Incoming Chair of ACR Appropriateness Criteria. J Am Coll Radiol. 2017;14(6):723-4.

\section{Publisher's Note}

Springer Nature remains neutral with regard to jurisdictional claims in published maps and institutional affiliations.

Ready to submit your research? Choose BMC and benefit from:

- fast, convenient online submission

- thorough peer review by experienced researchers in your field

- rapid publication on acceptance

- support for research data, including large and complex data types

- gold Open Access which fosters wider collaboration and increased citations

- maximum visibility for your research: over $100 \mathrm{M}$ website views per year

At $\mathrm{BMC}$, research is always in progress.

Learn more biomedcentral.com/submissions 